\title{
Antimalarial Phytochemicals Identification from Euphorbia Hirta against Plasmepsin Protease: an In Silico Approach
}

\author{
Ashish P. Shah, Ghanshyam R. Parmar, Girish U. Sailor, Avinash K. Seth \\ Department of Pharmacy, Sumandeep Vidyapeeth University, Gujarat, India
}

Corresponding author: Ashish Shah, Department of Pharmacy, Sumandeep Vidyapeeth University, At post; Piparia, Taluka: Waghodia, Dist: Vadodara-391760, Gujarat, India; E-mail: shah_ashishpharmacy@yahoo.co.in

Received: 03 Nov 2018 Accepted: 21 June 2019 Published: 31 Dec 2019

Citation: Shah AP, Parmar GR, Sailor GU, Seth AK. Antimalarial phytochemicals identification from Euphorbia hirta against plasmepsin protease: an in silico approach. Folia Med (Plovdiv) 2019;61(4):584-93. doi: 10.3897/folmed.61.e47965.

\begin{abstract}
Background: Aspartic protease found in plasmodium parasites such as plasmepsin I, II and IV plays an important role in the degradation of hemoglobin. The studies have shown that effective drug must be able to inhibit more than one type of plasmepsin to avoid further growth of parasites and to prevent resistance of drug. Therefore, plasmepsins are believed to be excellent drug target for malarial disease. Extract of the plant Euphorbia hirta has been proved to exert antimalarial activity. However, molecular mechanism of this activity was not described.

Aim: The aim of present investigation is to identify antimalarial phytochemicals of Euphorbia hirta as plasmepsin protease inhibitors using an in silico approach

Materials and methods: Docking studies were performed on three different protein targets plasmepsin I, II, and IV using iGEMDOCK. ADME and bioactivity predictions were done using molinspiration online tool. Toxicity studies were performed using ProTox-II online tool.

Results: In the docking studies seven compounds showed significant inhibitory activity with low docking score as compared to standard drug artemisinin. Six compounds showed no violations as per Lipinski rule. Bioactivity prediction states that all the compounds may act through enzyme inhibition. The results of in silico studies suggest that out of the eleven selected phytochemicals isorhamnetin and pinocembrin have more drug likeliness properties and lesser in silico toxicity with more binding affinity than artemisinin on all receptors.

Conclusion: These findings indicate that isorhamnetin and pinocembrin have promising potential for development of antimalarial drug as plasmepsin inhibitors.
\end{abstract}

\section{Keywords:}

ADMET, docking, Euphorbia hirta, malaria, plasmepsin

\section{INTRODUCTION}

Malaria is caused by plasmodium parasites and spread by the bite of female anopheles mosquito and its species. Malaria is a public health problem worldwide. In 2017, there were around 216 million cases of malaria worldwide. Ma- jority of malarial cases are seen in Africa, South-East Asia and Eastern Mediterranean zone. ${ }^{1}$ The risk of malarial disease is more in children, women during pregnancy, and non-immune travellers, refugees, displaced persons and labourers entering endemic areas. ${ }^{2,3}$ The antimalarial drugs either inhibit asexual phase or sexual phase of parasites.

Copyright by authors. This is an open access article distributed under the terms of the Creative Commons Attribution License (CC-BY 4.0), 
The drawback of currently available malarial chemotherapy is development of resistance. According to literature on the subject, there are no existing antimalarial drugs that have been developed on fully rational basis which inhibit specific target. The increase in morbidity caused by drug resistant malaria has inspired the scientists to search for suitable drug inhibitors, genetic basis of drug resistance and the new approaches to overcome drug resistance. ${ }^{4}$

Aspartic protease found in eukaryotic cells; this enzyme is known as plasmepsin. Hemoglobin degradation is one of the key processes for the survival of malarial parasites in human blood. ${ }^{5}$ There are some protease enzymes involved in the degradation of hemoglobin; out of these plasmepsin is one of the key enzyme responsible for initial cleavage of hemoglobin. There are ten types of plasmepsin that have been identified; among these plasmepsin I, II, and IV act at an early stage of hemoglobin degradation process. ${ }^{6,7}$

Plasmepsin is catalytic enzyme which contains two aspartic acid residues and these residues act as proton donor and proton acceptor, respectively. Aspartic acid residues also act as catalyst for hydrolysis of peptide bond. ${ }^{8,9}$ Hemoglobin degradation process starts with termination of phenylalanine and leucine in a-globin chains in hemoglobin.

Euphorbia hirta belongs to the family Euphorbiaceae; it is well known for its medicinal properties and widely used worldwide. ${ }^{10}$ This plant is distributed throughout India and Australia and found especially at roadside. ${ }^{11}$ Extracts of the plant contains various phytochemical constituents like flavonoid $^{12}$, alkaloid, resin, tannin ${ }^{13}$, etc., which is responsible for different types of biological activity. Various flavonoids present in the methanol extract reported for antimalarial activity. ${ }^{14,15}$

In the present study, we had performed in silico molecular docking study, ADMET profile and bioactivity prediction of flavonoids found in the methanol extract of Euphorbia hirta. The docking studies were performed with three different proteins: plasmepsin I, II, and IV to find out molecular interaction and binding affinity.

\section{MATERIALS AND METHODS}

The docking study was performed in DELL inspiron PC (4GB RAM, 1GB graphics card, and COREi3 processor with 500GB hard disc capacity). The iGEMDOCK software was used for docking and post screening analysis. ADME studies and bioactivity prediction were done using molinspiration online tool. Toxicity studies were performed using ProTox-II online tool.

\section{Preparation of ligands}

The structures of selected flavonoids were drawn using ChemBioDraw Ultra 12.0 in $2 \mathrm{D}$ format. Then $2 \mathrm{D}$ structures were exported to ChemBio3D Ultra 12.0 for energy minimization and correction of geometry. The outputs of the structures were saved in mol file which were directly used for docking, ADMET studies and bioactivity prediction (Fig. 1)

\section{Homology modeling}

The FASTA sequence of the target plasmepsin I, II, and IV of Plasmodium falciparum were obtained from protein database of NCBI. Plasmepsin I protein consists of 452 amino acids (accession No PKC49702.1, gene Id: 1304177790), plasmepsin II consist of 453 amino acids (accession No PKC49749.1, gene id: 1304177837) and plasmepsin IV consist of 449 amino acids (accession No PKC49878.1, gene id: 1304177966). These protein sequences were used for BLAST. The level of similarity exists within the protein data bank shown in BLAST results. From the BLAST results PDB id 3QS1 (plasmepsin I), 2BJU (plasmepsin II), and 5JOD (plasmepsin IV) were found with maximum similarity.

\section{Preparation of protein}

Crystal 3D structure of plasmepsin I [PDB id: $3 \mathrm{QRV}^{16}$ ], II [PDB id: 2BJU ${ }^{17}$ ] and IV [PDB id: 5JOD ${ }^{18}$ ] were obtained from protein databank. Structures of proteins were evaluated on the basis of Ramachandran plot using RAMPAGE (Fig. 2). It was described by Ramachandran plot that 1148 (88.4\%) residues of the predicted model of plasmepsin I (Fig. 2A) were in favoured region while 133 (10.2\%) were in allowed region and 17 (1.3\%) were in outlier region. Ramachandran predicted model of plasmepsin II (Fig. 2B) showed that 317 (96.9\%) residues of the predicted model of plasmepsin II were in favoured region while 10 (3.1\%) were in allowed region and $0(0 \%)$ were in outlier region. $\mathrm{Ra}-$ machandran predicted model of plasmepsin-IV (Fig. 2C) showed that $727(97.5 \%)$ residues of the predicted model of plasmepsin IV were in favoured region while 19 (2.5\%) were in allowed region and $0(0 \%)$ were in outlier region. $3 \mathrm{D}$ structures of all protein were minimized, water molecules were removed, and hydrogen and charges were added. Finally, 3D structures of protein saved in PDB format and were used for docking.

\section{Molecular docking}

The docking studies were performed to identify preferred orientation and molecular interactions of natural compounds with targeted proteins. The molecular docking studies were performed using iGEMDOCK software. ${ }^{19}$ Docking, screening and post-analysis of the designed compounds were done using iGEMDOCK program with the protein targets plasmepsin I, II, and IV. The binding sites of the targets were prepared and the energy minimized compound was imported. From the docking, wizard ligands were selected and the scoring function used was iGEMDOCK score. The binding site of the target was $8 \AA$. The empirical scoring function of iGEMDOCK was estimated as:

Fitness $=\mathrm{vdW}+$ Hbond + Elec . 


\section{In silico ADMET studies}

Pharmacokinetic properties of natural products were calculated using molinspiration online software tool (http:// www.molinspiration.com). In silico toxicity studies are faster and reduce the amount of animal experiments. In silico toxicity studies were performed using ProTox-II online tool. The properties such as organ toxicity, carcinogenicity, mutagenicity, cytotoxicity, and toxicity class were predicated.

\section{In silico bioactivity analysis}

The bioactivity score of selected natural products of $E$. hirta were evaluated using the tool Molinspiration Cheminformatics server (http://www.molinspiration.com). This technique uses large chemical databases information to identify new drug candidates. The tool first analyses training set of active molecules and compared with inactive molecules by using sophisticated Bayesian statistical model. Based on this, activity score is generated. The compound which gets high score may have high probability to be active.

\section{RESULT AND DISCUSSION}

\section{Molecular docking studies}

The molecular interactions of all ligands with various proteins were identified by performing molecular docking studies. The binding affinity (docking score) were compared with the standard drug artemisinin (Table 1). Out of the eleven selected compounds seven compounds (except<smiles>C[C@@H]1O[C@H](Oc2c(-c3ccc(O)cc3)oc3cc(O)cc(O)c3c2=O)[C@H](O)[C@@H](O)[C@H]1O</smiles>

Afzelin<smiles>COc1cc(-c2oc3cc(O)cc(O)c3c(=O)c2O)ccc1O</smiles>

Isorhamnetin<smiles>O=C1C[C@H](c2ccccc2)Oc2cc(O)cc(O)c21</smiles>

Pinocambrin<smiles>COc1cc2ccc(=O)oc2cc1OC</smiles><smiles>CC1(C)C2CCC1(C)C(O)C2</smiles>

camphol<smiles>Oc1cc(O)c2c(c1)O[C@H](c1ccc(O)c(O)c1)[C@H](O)[C@H]2O</smiles>

Leucocynidol<smiles>C[C@H]1O[C@H](Oc2c(-c3ccc(O)c(O)c3)oc3cc(O)cc(O)c3c2=O)[C@H](O)[C@@H](O)[C@@H]1O</smiles>

Quercitrin<smiles>CC(=O)OCC1O[C@@H](O[C@H]2C(O)[C@H](Oc3c(-c4ccc(O)c(O)c4)oc4cc(O)cc(O)c4c3=O)OC(CO)[C@H]2O)C(O)[C@@H](O)[C@@H]1O</smiles>

Euphorbianin<smiles></smiles>

Myricitrin<smiles>OC1C[C@H](O)C(O)C(O)C1O</smiles>

Quercitol

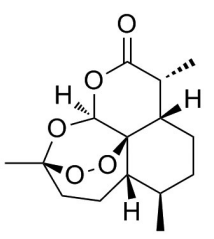

Artemisinin

Figure 1. Structures of selected phytoconstituents of E. hirta and standard drug artemisinin. 

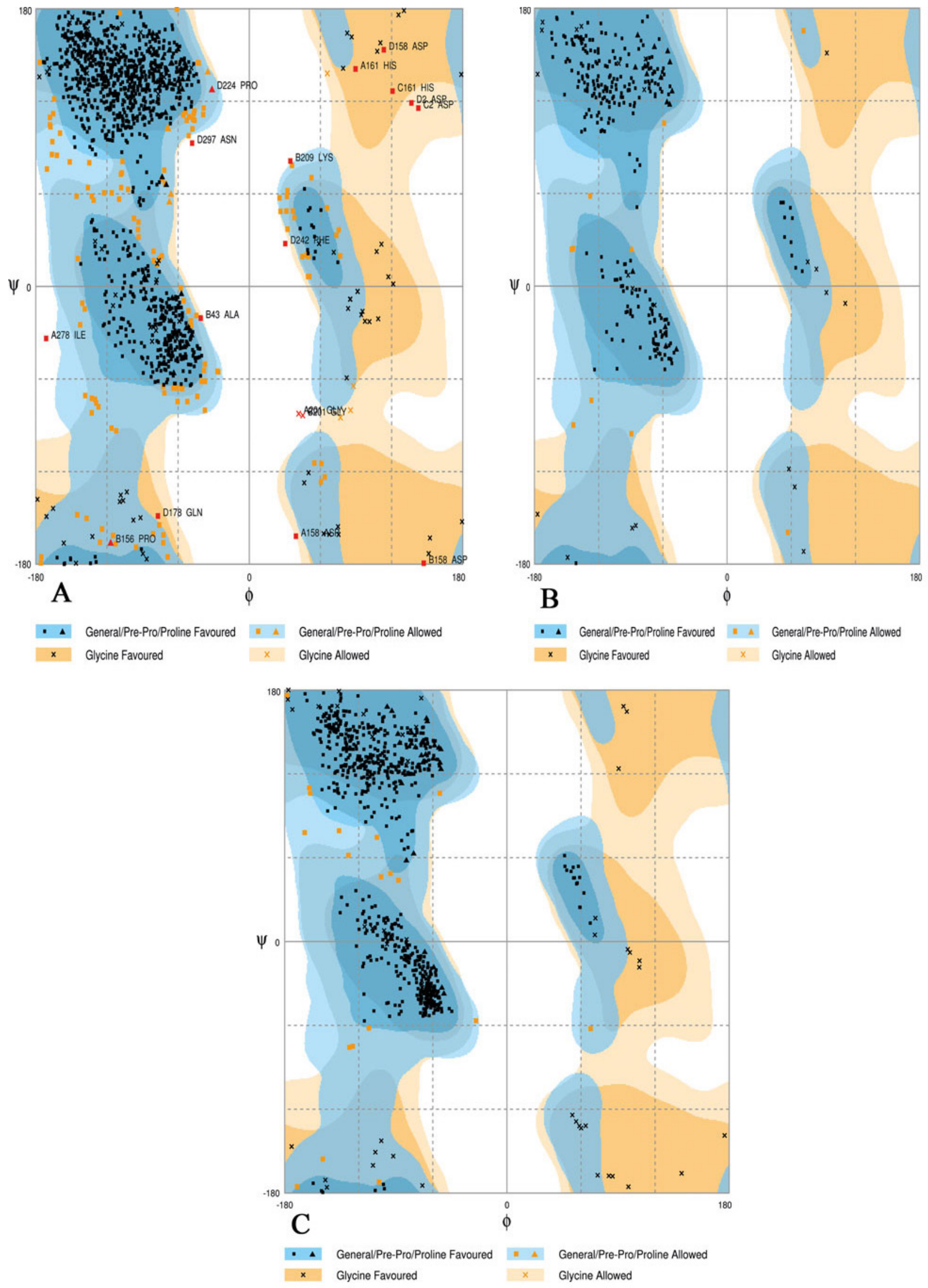

Figure 2. Ramachandran plot of predicted model of (A) plasmepsin I, (B) plasmepsin II, and (C) plasmepsin IV presented dihedral angles $\Phi$ against $\Psi$. Summary of the residues is at the bottom of the image. 
camphol, quercitol, scoparone, and scopoletin) showed low docking score as compared to standard drug artemisinin which means that they may have more binding affinity than the artemisinin. The pharmacological interactions were collected which is useful to identify lead compounds and its interacting mechanism. As per the iGEMDOCK, an interaction is considered as a pharmacological interaction if $\mathrm{Wj} \geq 0.4$. The residues within an $8 \AA$ A of area of ligand either through side chain or main chain were considered as active site residues. Predicted pharmacological interactions of all three receptor are shown in Table 2. Visualization of 3D interactions and orientation of compounds were done using PyMol visualization tool (Figs 3, 4).

\section{In silico ADMET analysis}

The compound may fail in pre-clinical studies if they don't have the required pharmacological properties to be considered as drug molecule. Compounds ADMET profile plays a crucial role in the development of drugs. Therefore compounds have to pass multiple filters to be considered as a novel drug. The ADME properties and drug likeliness of selected phytoconstituents of E. hirta are shown in Table 1. Drug likeliness were evaluated on the basis of Lipinski rule of five which states that a candidate is more likely to be orally active if: molecular weight is under 500, partition coefficient $(\log \mathrm{P})$ is less than five, hydrogen bond donors are

Table 1. Docking score of selected phytoconstituents of E. hirta

\begin{tabular}{lccccccccc}
\hline & \multicolumn{3}{c}{ Plasmepsin-I } & \multicolumn{3}{c}{ Plasmepsin-II } & \multicolumn{3}{c}{ Plasmepsin-IV } \\
\hline Compound & Total & VDW & HBond & $\begin{array}{c}\text { Total } \\
\text { Energy }\end{array}$ & VDW & HBond & $\begin{array}{c}\text { Total } \\
\text { Energy }\end{array}$ & VDW & HBond \\
\hline Afzelin & -126.76 & -100.71 & -26.0496 & -143.385 & -106.602 & -36.7828 & -105.049 & -78.3561 & -26.6925 \\
Camphol & -55.1537 & -46.6775 & -8.47615 & -64.3594 & -59.4297 & -4.92968 & -53.9983 & -44.3337 & -9.6646 \\
Euphorbianin & -141.016 & -117.044 & -23.9717 & -151.001 & -56.6462 & -94.355 & -130.754 & -93.5306 & -37.2239 \\
Isorhamnetin & -133.357 & -91.4404 & -41.9162 & -156.333 & -79.4785 & -76.8541 & -117.506 & -88.8532 & -28.6529 \\
Leucocyanidol & -99.0325 & -67.7888 & -31.2438 & -115.458 & -67.226 & -48.232 & -95.4614 & -65.1406 & -30.3207 \\
Myricitrin & -131.984 & -90.4002 & -41.5841 & -137.29 & -78.2991 & -58.9908 & -114.214 & -77.1603 & -37.0537 \\
Pinocembrin & -90.4797 & -66.2567 & -24.223 & -98.8994 & -76.2287 & -22.6707 & -79.5982 & -66.5476 & -13.0507 \\
Quercitol & -66.3883 & -36.7156 & -29.6727 & -77.418 & -32.7941 & -44.6239 & -66.1911 & -45.7189 & -20.4722 \\
Quercitrin & -132.938 & -95.2586 & -37.6794 & -132.529 & -80.8675 & -51.6615 & -113.025 & -76.7498 & -36.2748 \\
Scoparone & -68.9234 & -63.3262 & -5.59717 & -86.0838 & -83.0233 & -3.06049 & -64.1938 & -57.1938 & -7 \\
Scopoletin & -70.3021 & -52.8924 & -17.4096 & -98.4147 & -62.4521 & -35.9626 & -67.6348 & -51.5193 & -16.1155 \\
Artemisinin & -77.17 & -63.6956 & -13.4744 & -101.408 & -55.1377 & -46.2706 & -68.0108 & -61.3396 & -6.6712 \\
\hline VDW: Van & & & & & & & & &
\end{tabular}

VDW: Van der Waals; HBond: Hydrogen bond

Table 2. Predicted pharmacological interactions of all selected proteins

\begin{tabular}{lc}
\hline Protein & Predicted pharmacological interactions \\
\hline Plasmepsin-I (PDB id: 3QRV) & H-S-ASP-32 $(0.46)$, \\
& H-S-SER-32 $(1)$, \\
& V-S-TYR-75 $(\mathrm{O} .34)$, \\
& V-M-GLY-217 $(0.59)$, \\
& V-M-THR-218 $(0.54)$, \\
& V-S-PHE-242 $(1)$ \\
Plasmepain-II (PDB id: 2BJU) & H-M-GLY-216 $(0.36)$, \\
& V-S-METH-15 $(0.4)$ \\
Plasmepsin-IV (PDB id: 5JOD) & H-M-LYS-265 $(1)$, \\
& H-M-VAL-324 $(0.69)$, \\
V-S-PRO-181 $(1)$, \\
V-S-TYR-266 $(0.84)$, \\
V-S-TYR-309 $(0.73)$ \\
\hline
\end{tabular}

$\mathrm{H}$ and $\mathrm{V}$ are interaction types. $\mathrm{M}$ and $\mathrm{S}$ are Main chain and Side chain 

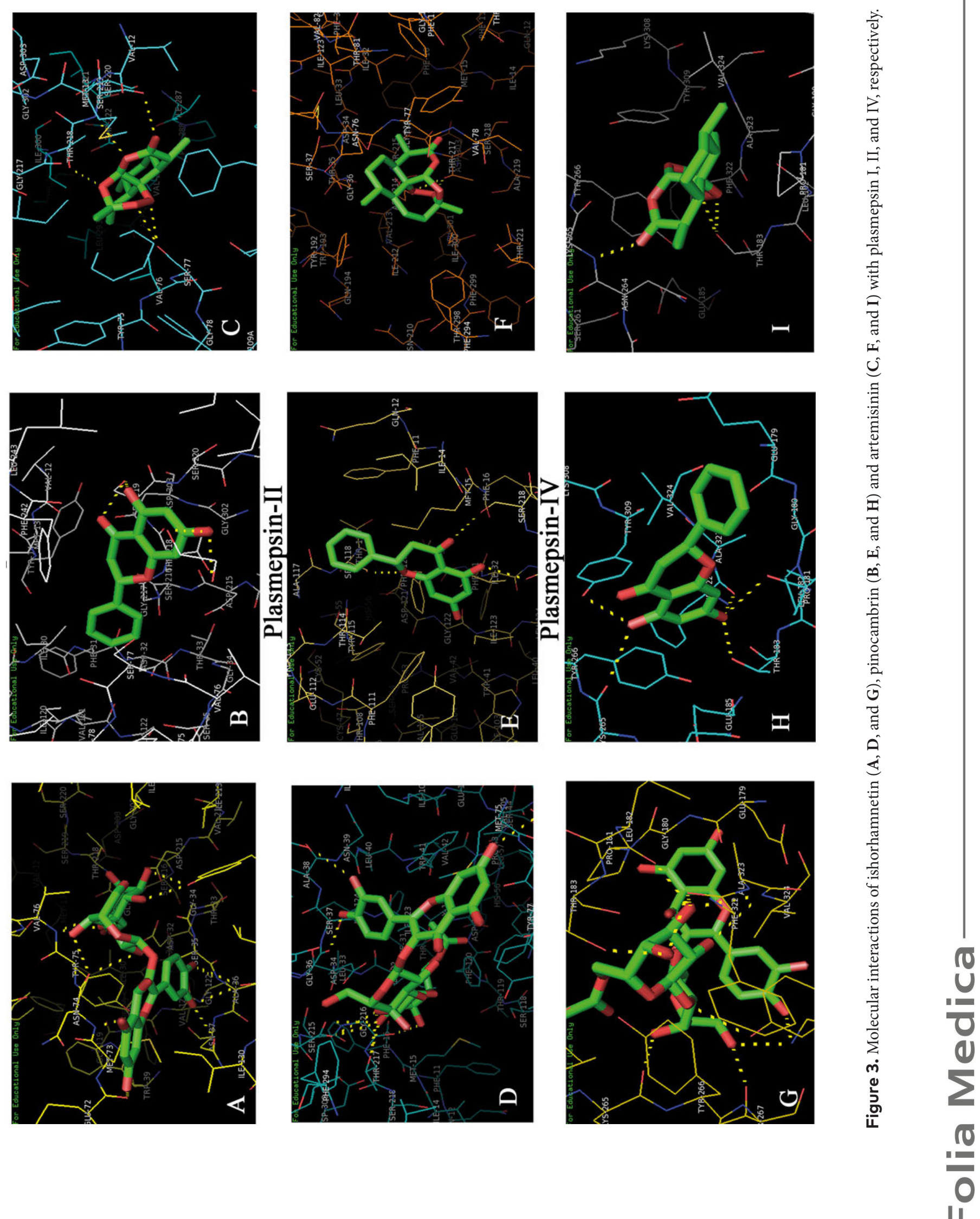

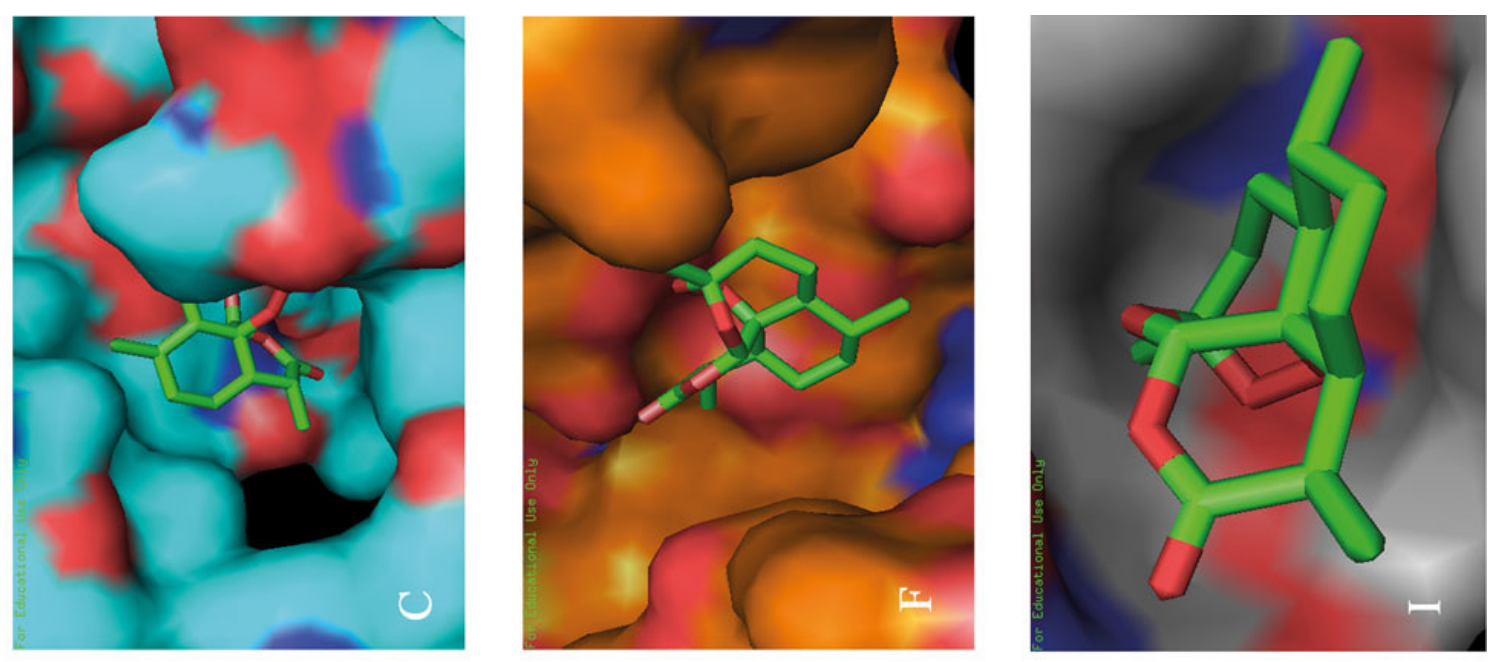

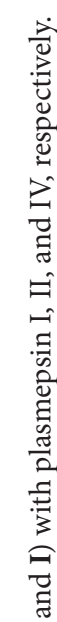
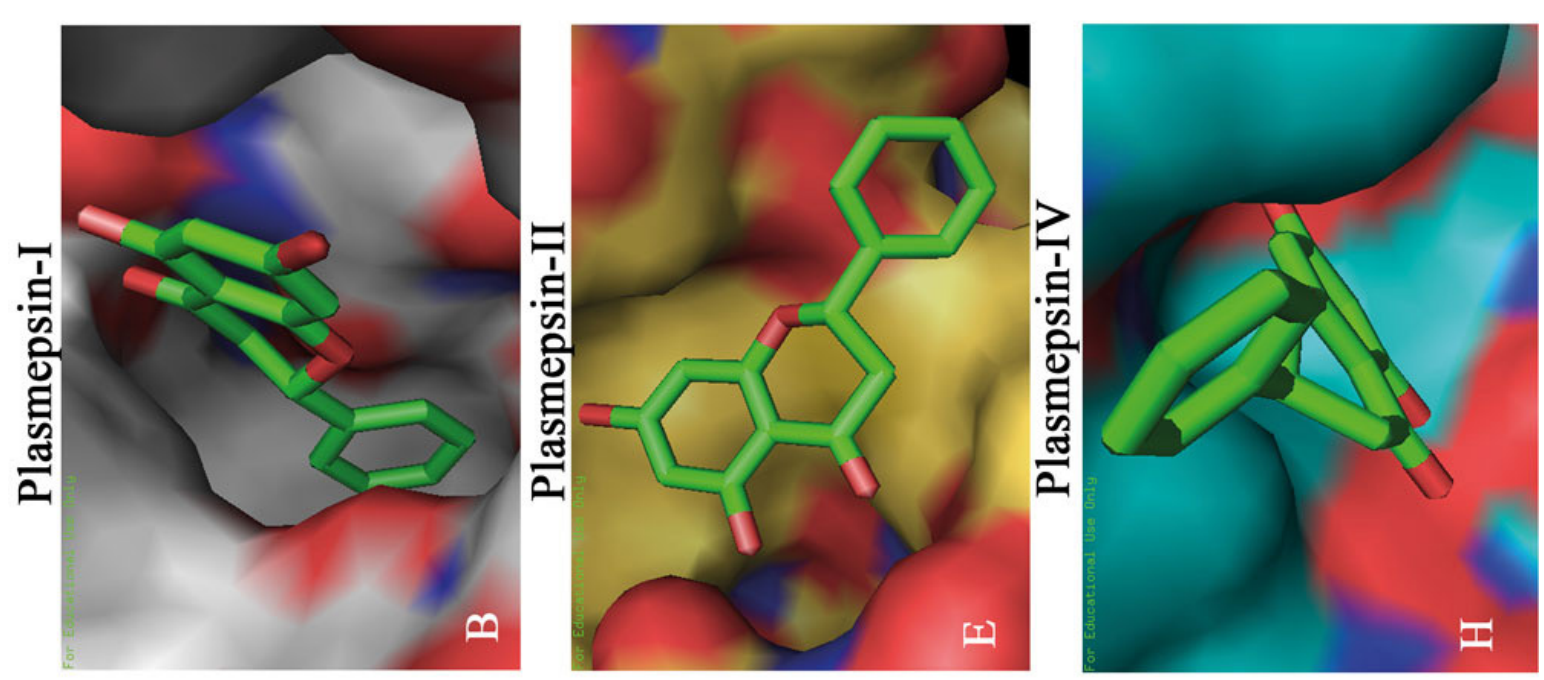

อี
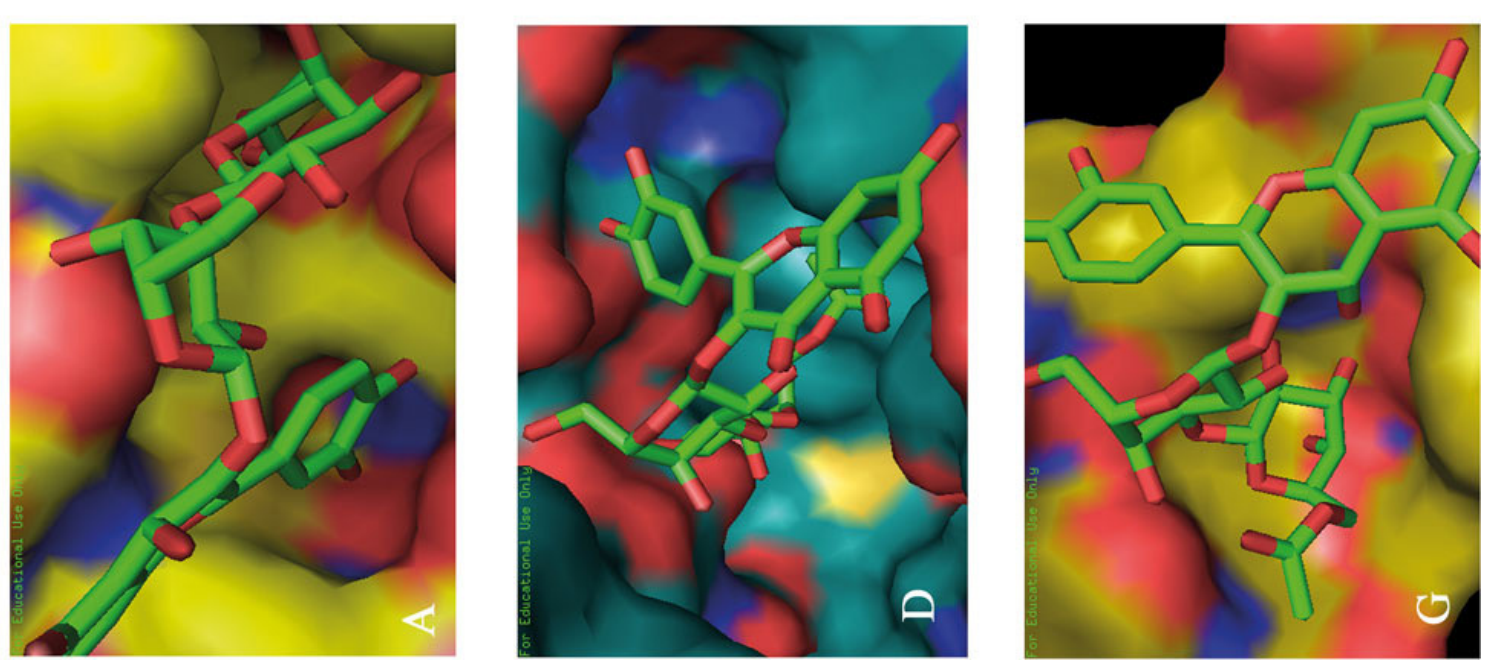

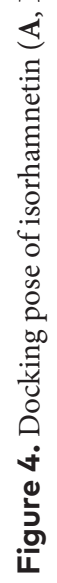

$\frac{10}{0}$ 
Table 3. In silico ADME studies of selected phytoconstituents of E. hirta

\begin{tabular}{lcccccccc}
\hline Sr No. & Compound Code & Molecular Weight & HBa & HBd & C LogP & TPSA & nrotb & $\begin{array}{c}\text { No of } \\
\text { violations }\end{array}$ \\
\hline 1 & Afzelin & 432.38 & 10 & 6 & 1.13 & 170.05 & 3 & 1 \\
2 & Camphol & 154.25 & 1 & 1 & 2.35 & 200.23 & 0 & 0 \\
3 & Euphorbianin & 668.55 & 18 & 10 & -1.58 & 295.23 & 9 & 3 \\
4 & Isorhamnetin & 316.26 & 7 & 4 & 1.99 & 120.36 & 2 & 0 \\
5 & Leucocyanidol & 306.27 & 7 & 6 & 0.36 & 130.60 & 1 & 1 \\
6 & Myricitrin & 464.38 & 12 & 8 & 0.35 & 210.50 & 3 & 2 \\
7 & Pinocembrin & 256.25 & 4 & 2 & 2.60 & 66.16 & 1 & 0 \\
8 & Quercitol & 164.16 & 5 & 5 & -2.13 & 101.14 & 0 & 0 \\
9 & Quercitrin & 448.38 & 11 & 7 & 0.64 & 190.28 & 3 & 2 \\
10 & Scoparone & 206.19 & 4 & 0 & 1.64 & 48.68 & 2 & 0 \\
11 & Scopoletin & 192.17 & 4 & 1 & 1.33 & 59.67 & 1 & 0 \\
12 & Artemisinin & 282.33 & 5 & 0 & 3.32 & 54.01 & 0 & 0 \\
\hline
\end{tabular}

HBa: Hydrogen bond accepter; HBd: Hydrogen bond doner; clogP: Conseus logP; TPSA: total polar surface area; nrotb: no. of rotatable bond

Table 4. In silico toxicity studies of selected phytoconstituents of E. hirta

\begin{tabular}{|c|c|c|c|c|c|c|}
\hline Compound & Hepatotoxicity & Carcinogenicity & Mutagenicity & Cytotoxicity & $\begin{array}{c}\mathrm{LD}_{50} \\
(\mathrm{mg} / \mathrm{kg})\end{array}$ & $\begin{array}{c}\text { Toxicity } \\
\text { class }\end{array}$ \\
\hline Afzelin & inactive & active & inactive & inactive & 5000 & 5 \\
\hline Camphol & inactive & inactive & inactive & inactive & 500 & 4 \\
\hline Euphorbianin & inactive & inactive & inactive & inactive & 500 & 5 \\
\hline Isorhamnetin & inactive & inactive & inactive & inactive & 500 & 5 \\
\hline Leucocyanidol & inactive & active & inactive & inactive & 2500 & 5 \\
\hline Myricitrin & inactive & inactive & inactive & inactive & 500 & 5 \\
\hline Pinocembrin & inactive & inactive & inactive & active & 200 & 4 \\
\hline Quercitol & inactive & inactive & inactive & inactive & 10,000 & 6 \\
\hline Quercitrin & inactive & active & inactive & inactive & 5000 & 5 \\
\hline Scoparone & inactive & active & inactive & inactive & 280 & 3 \\
\hline Scopoletin & inactive & inactive & inactive & inactive & 3800 & 5 \\
\hline Artemisinin & inactive & inactive & inactive & inactive & 4228 & 5 \\
\hline
\end{tabular}

no more than five, hydrogen bond acceptors are no more than ten, and the number of rotatable bonds should be no more than ten. ${ }^{20}$ Out of the 11 selected compounds, six compounds (camphol, isorhamnetin, pinocembrin, scoparone, quercitol, and scopoletin) show no violations as per Lipinski rule of five. Total polar surface area (TPSA) is a very useful parameter to identify polarity of molecule and important property for intestinal absorption, bioavailability, blood brain barrier penetration, etc. Compounds with polar surface area greater than $140 \AA$ have poor cell membrane permeability. The results shows that isorhamnetin, leucocyanidol, scoperone, quercitol and scopoletin have TPSA limit within the range (Table 3).
Results of in silico toxicity studies showed that all selected phytochemical belonged to toxicity class 4, 5, and 6, except quercetin (class 3). Afzelin, leucocyanidol, myricitrin, quercitrin and scoparone predicted as carcinogenic and pinocembrin were found to be cytotoxic (Table 4).

\section{In silico bioactivity analysis}

Bioactivity was measured by bioactivity score and categorized under three different ranges like more than 0 (having considerable biological activity), -0.5 to 0 (moderately active) and less than -0.5 (inactive). The bioactivity score were compared with standard drug artemisinin. The results of 
Table 5. Bioactivity prediction of selected phytoconstituents of E. hirta

\begin{tabular}{lccccccc}
\hline Sr No. & COMPOUND & GPCR & ICM & KI & NRL & PI & EI \\
\hline 1 & Afzelin & -0.01 & -0.09 & 0.05 & 0.16 & -0.05 & 0.36 \\
2 & Camphol & -0.47 & -0.51 & -1.57 & -0.84 & -0.80 & -0.23 \\
3 & Euphorbianin & -0.30 & -0.99 & -0.57 & -0.55 & -0.19 & 0.24 \\
4 & Isorhamnetin & -0.10 & 0.26 & 0.25 & 0.28 & -0.30 & 0.22 \\
5 & Leucocyanidol & 0.25 & 0.13 & 0.10 & 0.42 & 0.08 & 0.36 \\
6 & Myricitrin & -0.02 & -0.08 & 0.08 & 0.14 & -0.06 & 0.38 \\
7 & Pinocembrin & -0.0 & -0.20 & -0.32 & 0.37 & -0.17 & 0.21 \\
8 & Quercitol & -0.54 & 0.10 & -0.74 & -0.42 & -0.32 & 0.25 \\
9 & Quercitrin & -0.01 & -0.08 & 0.08 & 0.17 & 0.06 & 0.37 \\
10 & Scoparone & -0.93 & -0.65 & -0.88 & -0.81 & -1.03 & -0.27 \\
11 & Scopoletin & -1.0 & -0.65 & -0.95 & -0.81 & -1.16 & -0.24 \\
12 & Artemisinin & -0.17 & -0.31 & -0.65 & -0.00 & -0.19 & 0.39 \\
\hline
\end{tabular}

GPCR: G-protein couple receptor; ICM: ion channel modulator; KI: kinase inhibitor; NRL: nuclease receptor ligand; PI: protease inhibitor; EI: enzyme inhibitor

this study shows that all the selected phytochemicals have considerable enzyme inhibition activity which means that they may act through enzyme inhibition and give pharmacological action (Table 5).

\section{CONCLUSION}

Aspartic protease found in plasmodium parasites such as plasmepsin I, II, and IV play an important role in the degradation of hemoglobin. The studies have shown that effective drug must be able to inhibit more than one type of plasmepsin to avoid further growth of parasite and resistance of drug. Plasmepsin I, II, and IV act at an early stage of hemoglobin degradation process. In the current study we had performed in silico studies of phytoconstituents of E. hirta. In the docking studies seven compounds showed significant inhibitory activity with low docking score as compared to standard drug artemisinin. Six compounds showed no violations as per Lipinski rule. Bioactivity prediction states that all the compounds may act through enzyme inhibition. Drug likeliness, lower toxicity and more binding affinity of isorhamnetin and pinocembrin on all three receptors suggests that both may have ability to inhibit multiple plasmepsins and can be useful for the future treatment of malarial disease as plasmepsin inhibitors.

\section{REFERENCES}

1. WHO. World Malaria Report (World Health Organization, Geneva). 2017.

2. Ashley E, McGready R, Proux S. Francois Nosten Ã. Travel Med Infect Dis 2006; 4: 159-73.

3. Lalloo DG, Olukoya P, Olliaro P. Malaria in adolescence: burden of disease, consequences, and opportunities for intervention. Lancet Infect Dis 2006; 6(12): 780-93.

4. Fidock DA, Eastman RT, Ward SA, et al. Recent highlights in antimalarial drug resistance and chemotherapy research. Trends Parasitol 2008; 24(12): 537-44.

5. Francis SE, Sullivan Jr DJ, Goldberg, et al. Hemoglobin metabolism in the malaria parasite Plasmodium falciparum. Annu Rev Microbiol 1997; 51(1): 97-123.

6. Coombs GH, Goldberg DE, Klemba M, et al. Aspartic proteases of Plasmodium falciparum and other parasitic protozoa as drug targets. Trends Parasitol 2001; 17(11): 532-7.

7. Liu J, Gluzman IY, Drew ME, et al. The role of Plasmodium falciparum food vacuole plasmepsins. J Biol Chem 2005; 280(2): 1432-7.

8. Berry C, Humphreys MJ, Matharu P, et al. A distinct member of the aspartic proteinase gene family from the human malaria parasite Plasmodium falciparum. FEBS letters 1999; 447(2-3): 149-54.

9. Davies DR. The structure and function of the aspartic proteinases. Annu Rev Biophys Biophys Chem 1990; 19(1): 189-215.

10. Anjaria J, Parabia M, Bhatt G, et al. Nature Heals: a Glossary of Selected Indigenous Medicinal Plants of India. Ahmedabad: SRISTI Innovations; 1997.

11. Capasso F. Phytotherapy: A Quick Reference to Herbal Medicine. Berlin, Germany Springer-Verlag Berlin Heidelberg; 2003.

12. Yi W, Wei Q, Di G, et al. Phenols and flavonoids from the aerial part of Euphorbia hirta Chin J Nat Med 2012; 10(1): 40-2.

13. Yoshida T, Chen L, Shingu T, et al. Tannins and related polyphenols of Euphorbiaceous plants. IV: Euphorbins A and B, Novel Dimeric Dehydroellagitannins from Euphorbia hirta L. Chem Pharm Bull (Tokyo). 1988; 36(8): 2940-9.

14. Ajayi E, Adeleke M, Adewumi T, et al. Antiplasmodial activities of ethanol extracts of Euphorbia hirta whole plant and Vernonia amygdalina leaves in Plasmodium berghei-infected mice. J Taibah Univ Sci 2017; 11(6): 831-5.

15. Liu Y, Murakami N, Ji H, et al. Antimalarial flavonol glycosides from Euphorbia hirta. Pharm Biol 2007; 45(4): 278-81. 
16. Bhaumik P, Horimoto Y, Xiao H, et al. Crystal structures of the free and inhibited forms of plasmepsin I (PMI) from Plasmodium falciparum. J Struct Biol 2011; 175(1): 73-84.

17. Prade L, Jones AF, Boss C, et al. X-ray structure of plasmepsin II complexed with a potent achiral inhibitor. J Biol Chem 2005; 280(25): 23837-43.

18. Recacha R, Jaudzems K, Akopjana I, et al. Crystal structure of Plasmodium falciparum proplasmepsin IV: the plasticity of proplasmep- sins. Acta Crystallogr F Struct Biol Commun 2016; 72(Pt 9): 659-66.

19. Hsu K-C, Chen Y-F, Lin S-R, et al. iGEMDOCK: a graphical environment of enhancing GEMDOCK using pharmacological interactions and post-screening analysis. BMC Bioinformatics 2011; 12(1): S33.

20. Lipinski CA, Lombardo F, Dominy BW, et al. Experimental and computational approaches to estimate solubility and permeability in drug discovery and development settings. Adv Drug Deliv Rev 1997; 23(13): 3-25.

\title{
Идентисрикация антималярийных фритохимикатов Euphorbia Hirta против протеазы плазмеприна: подход in silico
}

\author{
Ашиш П. Шах, Гханшиям Р. Пармар, Гириш У. Саилор, Авинаш К. Сет \\ Кафедра фармации, Университет Сумандийн Видяпеет, Гуджарат, Индия
}

Адрес для корреспонденции: Ашиш П. Шах, Кафедра фармации, Университет Сумандийн Видяпеет, Пипариа, Талика: Вагходиа, Область Вадодара-391760, Гуджарат, Индия E-mail: shah_ashishpharmacy@yahoo.co.in; Тел: +919427942330

Дата получения: 03 ноября 2018 Дата приемки: 21 июня 2019 Дата публикации: 31 декабря 2019

Образец цитирования: Shah AP, Parmar GR, Sailor GU, Seth AK. Antimalarial phytochemicals identification from Euphorbia hirta against plasmepsin protease: an in silico approach. Folia Med (Plovdiv) 2019;61(4):584-93. doi: 10.3897/folmed.61.e47965.

\begin{abstract}
Абстракт
Введение: Аспарагиновая протеаза, обнаруженная у паразитов плазмодия, таких как плазмепсин I, II и IV, играет важную роль в деградации гемоглобина. Исследования показали, что эффективное лекарство должно быть способно ингибировать более одного типа плазмепсина, чтобы избежать дальнейшего роста паразитов и лекарственной устойчивости. Это считается отличным лекарством от малярийных заболеваний. Показано, что экстракт растения Euphorbia hirta обладает противомалярийным действием. Однако молекулярный механизм его действия не был описан.
\end{abstract}

Цель: Целью данного исследования является идентификация противомалярийных фитохимических Euphorbia hirta в качестве ингибиторов протеаз плазмепсина с помощью подхода In silico.

Материалы и методы: Исследования стыковки были проведены на трёх разных целевых белках плазмепсина I, II и IV c помощью iGEMDOCK. Поглощение, распределение, метаболизм и выведение (ADME) и оценки биологической активности были выполнены с использованием онлайн-инструмента Molinspiration, а исследования токсичности были выполнены с помощью онлайн-инструмента ProTox-II.

Результаты: В анализе докинга семь компонентов показали значительную ингибирующую активность с низким результатом по сравнению со стандартным препаратом артемизинином. Шесть ингредиентов не отклоняются согласно правилу Липинского. Согласно прогнозируемой биологической активности, все ингредиенты могут воздействовать на ингибирование энзимов. Результаты исследований in silico показывают, что из одиннадцати выбранных фитохимикатов изорамнетин и пинохембрин обладают более подобными лекарственным свойствам свойствами и обладают более низкой токсичностью in silico c более высокой аффинностью связывания, чем у артемизинина на всех рецепторах.

Выводы: Эти данные указывают на то, что изохамнетин и пиноцембринимат имеют многообещающий потенциал для разработки противомалярийных препаратов в качестве ингибиторов плазмепсина.

\section{Ключевые слова}

ADMET, Euphorbia hirta, докинг, пласмепсин, малярия 